\title{
Keanekaragaman dan Kemelimpahan Serangga di Hutan Bromo Karangannyar Sebagai Sumber Alternatif Belajar Biologi di SMA
}

\author{
Hartini ${ }^{*}$, Nur Rokhimah Hanik. ${ }^{2}$, Tri Wiharti. ${ }^{3}$ \\ ${ }^{123}$ Program Studi Pendidikan Biologi Universitas Veteran Bangun Nusantara Sukoharjo \\ *Alamat email koresponden: bio_anwary@yahoo.com
}

\begin{abstract}
Abstrak
Penelitian ini bertujuan untuk untuk mengetahui indeks keanekaragaman dan kemelimpahan serangga di Hutan Bromo Karanganyar, mengetahui faktor biotik dan abiotik apa saja yang mempengaruhi keanekaragaman dan kemelimpahan serangga dan untuk memperoleh salah satu alternatif sumber belajar biologi di SMA khususnya tentang Keanekaragaman hayati. Penelitian ini dilaksanakan pada Maret- April 2016 di Hutan Bromo Desa Sinongko Kelurahan Gedong Kabupaten Karanganyar dengan menggunakan metode estimasi populasi Lincoln- Peterson dan menghitung langsung. Teknik pengumpulan data dengan penangkapan dan dokumentasi. Analisis data dengan tiga cara yaitu mendiskripsikan cirri-ciri serangga, menghiting INP dan H'. Hasil penelitian ini menunjukkan bahwa keanekaragaman serangga di Hutan Bromo Kabupaten Karanganyar termasuk dalam kategori sedang yaitu berada pada $1,5 \geq \mathrm{H}^{\prime} \geq 3,5$. Indeks kemelimpahan serangga (INP) tertinggi terjadi pada penelitian pagi hari yaitu ordo Collembola pada genus Entomobrya dengan nilai 19,14, sedangkan terendah pada pagi hari yaitu ordo Dermaptera pada genus Euborellia dengan nila 6,1. Hasil penelitian ini dapat dimanfaatkan di Sekolah Menengah Atas sebagai salah satu alternative sumber belajar biologi tentang Keanekaragaman khususnya tentang insekta.
\end{abstract}

Kata Kunci : Keanekaragaman, Kemelimpahan, Serangga, Sumber Belajar biologi.

\section{Diversity and abundance of insects in Bromo Karanganyar Forest as an alternative source of learning biology in high school}

\author{
Hartini $^{1^{*}}$, Nur Rokhimah Hanik. ${ }^{2^{*}}$, Tri Wiharti. ${ }^{3^{*}}$ \\ ${ }^{231}$ Biology Education Departement, Universitas Veteran Bangun Nusantara Sukoharjo \\ *Correspondent's email address: bio_anwary@yahoo.com
}

\begin{abstract}
This study aims to determine the diversity and abundance index of insects in Bromo Karanganyar Forest, to know what biotic and abiotic factors affect the diversity and abundance of insects and to obtain an alternative source of biology learning in high school, especially about biodiversity. This research was conducted in March-April 2016 in the Bromo Forest of Sinongko Village, Gedong Village, Karanganyar Regency using the Lincoln-Peterson population estimation method and counting directly. Techniques for collecting data with capture and documentation. Data analysis is done in three ways, namely describing the characteristics of insects, hitting INP and H'. The results of this study indicate that the diversity of insects in the Bromo Forest in Karanganyar Regency is included in the medium category which is at $1.5 \geq H \geq 3.5$. The highest insect abundance index (INP) occurred in the morning study, namely the Collembola order in the genus Entomobrya with a value of 19.14, while the lowest in the morning was the order Dermaptera in the genus Euborellia with indigo 6.1. The results of this study can be used in high schools as an alternative source of learning biology about diversity especially about insects .
\end{abstract}

Keywords: Diversity, Abundance, Insects, Learning Resources for biology. 


\section{PENDAHULUAN}

Mata pelajaran biologi merupakan salah satu bagian dari sains yang berkaitan dengan cara mencari tahu gejala alam secara sistematis, sehingga dalam mempelajari ilmu biologi bukan hanya penguasaan kumpulan pengetahuan yang berupa fakta-fakta, konsep-konsep, atau prinsip-prinsip saja tetapi juga merupakan suatu proses penemuan, sehingga dapat membantu peserta didik untuk memperoleh pemahaman yang lebih mendalam tentang alam sekitar (Aria Seprianda, dkk, 2012).

Berkaitan dengan hal tersebut, salah satu permasalahan pembelajaran di SMA adalah terbatasnya sumber belajar yang digunakan siswa khususnya pokok bahasan keanekaragaman hayati tertuang pada kompetensi dasar yang sudah ditetapkan dalam silabus yaitu "Mendeskripsikan ciri-ciri Filum dalam Dunia Hewan dan peranannya bagi kehidupan" didalam kompetensi dasar tersebut dalam kegiatan pembelajaran salah satunya siswa dituntut untuk mengamati keanekaragaman spesies hewan.

Berdasarkan kompetensi dasar dan tuntutan pengalaman belajar tersebut, maka evaluasi pada materi ini meliputi pemahaman siswa terhadap materi keanekaragaman hayati khususnya keanekaragaman spesies serangga yang berada di hutan Bromo Kabupaten Karanganyar. Pemahaman secara menyeluruh terhadap materi dan pengalaman belajar dapat diberikan kepada siswa melalui kegiatan belajar mengajar dikelas sesuai dengan acuan dalam kompetensi dasar, pengalaman belajar dan indikator yang telah ditetapkan dalam kurikulum.

Hutan Bromo di Kabupaten Karanganyar yang memiliki luas kurang lebih 115 hektar adalah salah satu keanekaragaman hayati yang dimiliki oleh Indonesia.
Jika membahas tentang keanekaragaman hayati tidak jauh pembahasan kita mengenai ekologi. Menurut Soedjiran Resosoedarmo, dkk (1985:1), Ekologi merupakan ilmu yang mempelajari hubungan timbal balik antara makhluk hidup dengan lingkungannya. Berdasarkan pernyataan tersebut di Hutan Bromo Kabupaten Karanganyar yang termasuk dalam jenis hutan lindung yang heterogen tentunya terdapat ekosistem yang sangat melimpah didalamnya. Berbagai jenis tumbuhan yang terdapat di hutan tersebut dapat tumbuh baik salah satunya dipengaruhi oleh tanah yang subur.

Banyak serangga meluangkan sebagian atau seluruh hidup mereka di dalam tanah. Secara umum tanah bagi serangga berfungsi sebagai tempat hidup, tempat pertahanan, dan seringkali makanan (Borror et al, 1997). Sedangkan peranan terpenting dari serangga dalam ekosistem adalah sebagai perombak bahan organik yang tersedia bagi tumbuhan hijau. Menurut Daly (1981), serangga - serangga ini biasa ditemukan di tempat teduh, tanah yang lembab, sampah, padang rumput, di bawah kayu lapuk, dan tempat lembab yang serupa.

Keberadaan serangga di suatu lingkungan dipengaruhi oleh faktor faktor lingkungan, baik itu faktor biotik maupun faktor abiotik. Faktor abiotik meliputi tanah, air, suhu, cahaya, dan atmosfir. Sedangkan faktor biotik adalah organisme lain yang juga terdapat dihabitatnya.( Suin .1989).

Menurut Winarno et al (1997), keanekaragaman hayati berperan penting dalam menjaga kestabilan ekosistem. Keanekaragaman jenis yang tinggi menunjukkan bahwa suatu komunitas memiliki kompleksitas yang tinggi. Interaksi akan melibatkan transfer energi (jaring makanan), predasi, kompetisi, dan pembagian relung (Soegianto, 1994).

Keanekaragaman serangga di setiap tempat berbeda - beda, keanekaragaman rendah terdapat pada komunitas dengan 
lingkungan yang ekstrim, misalnya daerah kering, tanah miskin, dan pegunungan tinggi. Sedangkan keanekaragaman tinggi terdapat di daerah dengan komunitas lingkungan optimum, misalnya daerah subur, tanah kaya, dan daerah pegunungan. (Resosoedarmo et al, 1985).

Berdaasarkan latar belakang tersebut maka peneliti tertarik untuk melakukan penelitian dengan judul Keanekaragamandan Kemelimpahan Serangga di Hutan Bromo Kabupaten Karanganyar sebagai Salah Satu Alternatif Sumber Belajar Biologi di SMA.

\section{METODE}

Penelitian dilakukan di Hutan Bromo Kabupaten Karanganyar. Penelitian dilaksanakan pada Maret - April 2016. Penelitian ini merupakan penelitian deskriptif kuantitatif eksplorasi Instrumen yang digunakan pada penelitian ini berupa teknik penangkapan langsung, metode estimasi populasi Lincoln- Peterson, serta indeks keanekaragaman Shanon dan indeks dominansi Simpson. Subjek yang akan diteliti adalah seluruh serangga yang ada di Wana Wisata Hutan Bromo Kabupaten Karanganyar tahun 2016. Dengan pengamatan dibagi menjadi 5 stasiun ditentukan berdasarkan metode kombinasi antara cara jalur dan cara garis petak.

Rute sampling di bagi menjadi 5 stasiun yaitu di ambil bagian barat, timur, utara, selatan, dan tengah. Kegiatan di mulai dengan mengukur suhu, kelembaban, dan $\mathrm{pH}$ untuk memastikan cuaca dan mengetahui pengaruh terhadap keberadaan serangga Pada setiap stasiun dilakukan sampling pelemparan perangkap sebanyak 5 kali Sehingga jumlah keseluruhan sampling sebanyak 25 kali lemparan dan waktu yang dibutuhkan 125 menit dalam 1 hari. Teknik pengumpulan data menggunakan teknik penangkapan serangga dan dokumentasi. Teknik analisis data menggunakan analisis kuantitatif. Untuk menghitung dominansi suatu jenis serangga terhadap komunitasnya menurut
Soegianto (1994) dengan menggunakan rumus: Jumlah dari ke dua pengukuran $(\mathrm{KR}+\mathrm{FR})$. Indeks keanekaragaman dihitung dengan menggunakan rumus dari Shannon and Wiener (1949) dalam Ludwig and Reynolds (1988) ; Odum (1998) ;

$\mathrm{H}^{\prime}=-\sum_{\mathrm{i}}($ pi ln pi $)$
$\mathrm{Pi}=\frac{\mathrm{ni}}{\mathrm{N}}$

Keterangan:

$H^{\prime}$ : Indeks keanekaragaman Shannon and Wiener

$n i$ : Jumlah jenis individu dari jenis ke-i

$N$ : Jumlah total individu dari seluruh jenis spesies

$P i$ :Proporsi dari jumlah individu jenis i dengan jumlah individu dari seluruh jenis spesies.

Nilai H' berkisar antara: $1.5-3.5$

1,5: Keanekaragaman rendah

1,5 - 3,5 : Keanekaragaman sedang

3,5 : Keanekaragaman tinggi (Rahmawaty, 2006)

\section{HASIL DAN PEMBAHASAN}

Lokasi penelitian di Hutan Bromo Karanganyar yang letaknya $\pm 5 \mathrm{~km}$ kearah kota Karanganyar. Kawasan hutan penelitian ini ditumbuhi berbagai jenis pohon, termasuk pohon langka seperti pohon cendana."(Dodik.2011).

Pengamatan serangga di Hutan Bromo dilakukan sebanyak 3 kali yaitu diwaktu pagi, siang dan sore dengan pemilihan stasiun yang sama. Selain pengamatan langsung di Hutan Bromo juga dilakukan analisis kadar C-organik tanah di Laboratorium Biologi Tanah Fakultas Pertanian UNS Surakarta. Penelitian dilaksanakan pada bulan April-Mei 2016. 
Journal of Biology Learning

Volume 1, Issue 1, Page 36 - 46, March 2019

\section{Analisis Keanekaragaman dan Kemelimpahan Serangga Pagi Hari}

Tabel 1. Kemelimpahan Serangga pada Pagi Hari

\begin{tabular}{|c|c|c|c|c|c|c|c|c|c|c|c|c|c|}
\hline \multirow{2}{*}{ No } & \multirow{2}{*}{ ORDO } & \multirow{2}{*}{ GENUS } & \multicolumn{5}{|c|}{ STASIUN } & \multirow{2}{*}{ JMLH } & \multirow{2}{*}{$\mathbf{K}$} & \multirow{2}{*}{$\begin{array}{l}\text { KR } \\
(\%)\end{array}$} & \multirow{2}{*}{$\mathbf{F}$} & \multirow{2}{*}{$\begin{array}{c}\text { FR } \\
(\%)\end{array}$} & \multirow{2}{*}{ NP } \\
\hline & & & 1 & 2 & 3 & 4 & 5 & & & & & & \\
\hline 1 & Collembola & Isotomorus & 10 & 6 & 10 & 8 & 10 & 50 & 10 & 4,73 & 1 & 6,09 & 9,96 \\
\hline 2 & Collembola & Entomobrya & 9 & 12 & 24 & 59 & 22 & 138 & 27,6 & 13,05 & 1 & 6,09 & 19,14 \\
\hline 3 & Collembola & Hydroisotoma & 10 & 9 & 14 & 24 & 8 & 74 & 14,8 & 7,01 & 1 & 6,09 & 13,1 \\
\hline 4 & Collembola & Proisotoma & 9 & 16 & 13 & 12 & 4 & 64 & 12,8 & 6,05 & 1 & 6,09 & 12,14 \\
\hline 5 & Collembola & Vertagopus & 3 & 10 & 4 & 15 & 14 & 63 & 12,6 & 5,96 & 1 & 6,09 & 12,05 \\
\hline 6 & Hymenoptera & Mirmica & 0 & 5 & 8 & 10 & 3 & 28 & 5,6 & 2,64 & 0,8 & 4,87 & 7,51 \\
\hline 7 & Hymenoptera & Iridomyrmex & 2 & 0 & 11 & 12 & 6 & 35 & 7 & 3,31 & 0,8 & 4,87 & 8.18 \\
\hline 8 & Hymenoptera & Cardiocondyla & 8 & 5 & 10 & 7 & 6 & 41 & 8,2 & 3.87 & 1 & 6,09 & 14,29 \\
\hline 9 & Coleoptera & Mycetophagus & 2 & 0 & 3 & 10 & 4 & 20 & 4 & 1,89 & 08 & 4,87 & 6,76 \\
\hline 10 & Coleoptera & Platydracus & 3 & 8 & 0 & 11 & 6 & 42 & 8,4 & 3,97 & 0,8 & 4,87 & 8,84 \\
\hline 11 & Coleoptera & Dendrocnotus & 2 & 0 & 6 & 4 & 6 & 29 & 5,8 & 2,74 & 0,8 & 4,87 & 7,61 \\
\hline 12 & Coleoptera & Batrisodes & 10 & 7 & 10 & 5 & 8 & 43 & 8,6 & 4,06 & 1 & 6,09 & 14,69 \\
\hline 13 & Coleoptera & Harpalus & 4 & 0 & 5 & 3 & 4 & 23 & 4,6 & 2,17 & 0,8 & 4,87 & 7.04 \\
\hline 14 & Coleoptera & Dyscinetus & 4 & 14 & 15 & 17 & 12 & 80 & 16 & 7,56 & 1 & 6,09 & 13,65 \\
\hline 15 & Coleoptera & Phaedonia & 17 & 3 & 24 & 65 & 6 & 123 & 24,6 & 11,63 & 1 & 6,09 & 17,72 \\
\hline 16 & Coleoptera & Paederus & 0 & 21 & 24 & 30 & 15 & 103 & 20,6 & 9,74 & 0,8 & 4,87 & 14,61 \\
\hline 17 & Blattaria & Periplaneta & 2 & 5 & 2 & 6 & 2 & 32 & 6,4 & 3,02 & 1 & 6,09 & 9,11 \\
\hline 18 & Blattaria & Platyzosteria & 5 & 0 & 5 & 12 & 11 & 49 & 9,8 & 4,63 & 0,8 & 4,87 & 9,5 \\
\hline \multicolumn{3}{|c|}{ JUMLAH } & 105 & 123 & 192 & 313 & 148 & 1037 & 2114 & 100 & 16,4 & 100 & 200 \\
\hline
\end{tabular}

Tabel 2. Keanekaragaman Serangga pada Pagi Hari

\begin{tabular}{cllcccc}
\hline No & ORDO & GENUS & JUMLAH & Pi & LnPi & -Pi(LnPi) \\
\hline 1 & Collembola & Isotomorus & 50 & 0,048 & $-3,036$ & 0,145 \\
2 & Collembola & Entomobrya & 138 & 0,133 & $-2,017$ & 0,268 \\
3 & Collembola & Hydroisotoma & 74 & 0,071 & $-2,645$ & 0,187 \\
4 & Collembola & Proisotoma & 64 & 0,061 & $-3,796$ & 0,170 \\
5 & Collembola & Vertagopus & 63 & 0,060 & $-3,813$ & 0,168 \\
6 & Hymenoptera & Mirmica & 28 & 0,027 & $-3,611$ & 0,097 \\
7 & Hymenoptera & Iridomyrmex & 35 & 0,033 & $-3,411$ & 0,112 \\
8 & Hymenoptera & Cardiocondyla & 41 & 0,039 & $-3,244$ & 0,126 \\
9 & Coleoptera & Mycetophagus & 20 & 0,019 & $-3,963$ & 0,075 \\
10 & Coleoptera & Platydracus & 42 & 0,040 & $-3,218$ & 0,128 \\
11 & Coleoptera & Dendrocnotus & 29 & 0,027 & $-3,611$ & 0,097 \\
12 & Coleoptera & Batrisodes & 43 & 0,041 & $-3,194$ & 0,130 \\
13 & Coleoptera & Harpalus & 23 & 0,221 & $-3,816$ & 0,083 \\
14 & Coleoptera & Dyscinetus & 80 & 0,077 & $-3,256$ & 0,197 \\
15 & Coleoptera & Phaedonia & 123 & 0,118 & $-2,137$ & 0,255 \\
16 & Coleoptera & Paederus & 103 & 0,099 & $-2,312$ & 0,228 \\
17 & Blattaria & Periplaneta & 32 & 0,030 & $-3,508$ & 0,105 \\
18 & Blattaria & Platyzosteria & 49 & 0,047 & $-3,057$ & 0,143 \\
\hline & & & & & H'=2,714
\end{tabular}


Tabel 3. Pengukuran Faktor Abiotik

\begin{tabular}{ccccccc}
\hline \multirow{2}{*}{$\begin{array}{c}\text { STASIUN } \\
\text { KE- }\end{array}$} & $\begin{array}{c}\text { SUHU } \\
\text { TANAH } \\
\left({ }^{\circ}\right)\end{array}$ & $\begin{array}{c}\text { KELEMBABAN } \\
\text { TANAH( \%) }\end{array}$ & $\begin{array}{c}\text { pH } \\
\text { TANAH }\end{array}$ & $\begin{array}{c}\text { SUHU UDARA } \\
\left({ }^{\circ} \mathbf{C}\right)\end{array}$ & $\begin{array}{c}\text { KELEMBABAN } \\
\text { UDARA }\left({ }^{\circ} \mathbf{C}\right)\end{array}$ & $\begin{array}{c}\text { KADAR C- } \\
\text { ORGANIK } \\
\text { TANAH(\%) }\end{array}$ \\
\hline 1 & 26 & 50 & 6 & 27 & 94 & 1,08 \\
2 & 25 & 40 & 6 & 28 & 94 & 1,29 \\
3 & 27 & 60 & 7 & 27 & 95 & 1,96 \\
4 & 26 & 65 & 7 & 27 & 95 & 2,20 \\
5 & 26 & 50 & 7 & 28 & 94 & 1,66 \\
\hline RATA- & & & & & & \\
RATA & 26 & 53 & 6,6 & 27,4 & 94,4 & 8,19 \\
\hline
\end{tabular}

Analisis Keanekaragaman Dan Kemelimpahan Serangga siang Hari

Tabel 4. Pengamatan Kemelimpahan Serangga pada Siang Hari

\begin{tabular}{|c|c|c|c|c|c|c|c|c|c|c|c|c|c|}
\hline \multirow{2}{*}{ NO } & \multirow{2}{*}{ ORDO } & \multirow{2}{*}{ GENUS } & \multicolumn{5}{|c|}{ STASIUN } & \multirow{2}{*}{ JMLH } & \multirow{2}{*}{$\mathbf{K}$} & \multirow{2}{*}{$\begin{array}{l}\text { KR } \\
(\%)\end{array}$} & \multirow{2}{*}{$\mathbf{F}$} & \multirow{2}{*}{$\begin{array}{c}\text { FR } \\
(\%)\end{array}$} & \multirow{2}{*}{ NP } \\
\hline & & & 1 & 2 & 3 & 4 & 5 & & & & & & \\
\hline 1 & Collembola & Isotomorus & 5 & 7 & 3 & 6 & 2 & 23 & 4,6 & 2,02 & 1 & 5,31 & 7,33 \\
\hline 2 & Collembola & Entomobrya & 4 & 5 & 7 & 8 & 7 & 31 & 6,2 & 2,73 & 1 & 5,31 & 8,04 \\
\hline 3 & Collembola & Hydroisotoma & 5 & 8 & 7 & 6 & 7 & 33 & 6,6 & 2,91 & 1 & 5,31 & 8,22 \\
\hline 4 & Diptera & Drosophila & 5 & 9 & 3 & 6 & 8 & 31 & 6,2 & 2,73 & 1 & 5,31 & 8,04 \\
\hline 5 & Hymenoptera & Cardiocondyla & 10 & 8 & 9 & 8 & 7 & 42 & 8,4 & 3,70 & 1 & 5,31 & 9,01 \\
\hline 6 & Hymenoptera & Mirmica & 17 & 0 & 17 & 12 & 11 & 57 & 11,4 & 5,02 & 0,8 & 4,25 & 9,27 \\
\hline 7 & Hymenoptera & Iridomyrmex & 0 & 7 & 3 & 16 & 3 & 29 & 5,8 & 2,17 & 0,8 & 4,25 & 6,42 \\
\hline 8 & Hymenoptera & Dolichoderus & 23 & 27 & 27 & 24 & 35 & 136 & 27,2 & 11,99 & 1 & 5,31 & 17,3 \\
\hline 9 & Coleoptera & Mycetophagus & 24 & 23 & 11 & 12 & 0 & 70 & 14 & 6,17 & 0,8 & 4,25 & 10,42 \\
\hline 10 & Coleoptera & Platydracus & 0 & 14 & 13 & 9 & 30 & 66 & 13,2 & 5,82 & 0,8 & 4,25 & 10,07 \\
\hline 11 & Coleoptera & Dendrocnotus & 4 & 11 & 4 & 12 & 3 & 34 & 6,8 & 2,99 & 1 & 5,31 & 8,3 \\
\hline 12 & Coleoptera & Batrisodes & 15 & 27 & 19 & 31 & 32 & 124 & 24,8 & 10,93 & 1 & 5,31 & 16,24 \\
\hline 13 & Coleoptera & Harpalus & 33 & 17 & 23 & 27 & 14 & 114 & 22,8 & 8,54 & 1 & 5,31 & 13,85 \\
\hline 14 & Coleoptera & Dyscinetus & 6 & 12 & 2 & 13 & 6 & 39 & 7,8 & 2,92 & 1 & 5,31 & 8,23 \\
\hline 15 & Coleoptera & Phaedonia & 7 & 9 & 5 & 6 & 3 & 30 & 6 & 2,24 & 1 & 5,31 & 7,55 \\
\hline 16 & Coleoptera & Paederus & 4 & 7 & 14 & 11 & 16 & 52 & 10,4 & 3,89 & 1 & 5,31 & 9,2 \\
\hline 17 & Blattaria & Periplaneta & 7 & 10 & 23 & 15 & 13 & 68 & 13,6 & 5,09 & 1 & 5,31 & 10,4 \\
\hline 18 & Blattaria & Platyzosteria & 24 & 11 & 21 & 14 & 8 & 78 & 15,6 & 5,84 & 1 & 5,31 & 11,15 \\
\hline 19 & Orthoptera & Gryllus & 15 & 0 & 23 & 2 & 16 & 56 & 11,2 & 4,19 & 0,8 & 4,25 & 8,44 \\
\hline 20 & Dermaptera & Euborellia & 0 & 5 & 6 & 6 & 4 & 21 & 4,2 & 1,85 & 0,8 & 4,25 & 6,1 \\
\hline \multicolumn{3}{|c|}{ Jumlah } & 208 & 217 & 240 & 244 & 225 & 1134 & 226,8 & 100 & 18,8 & 100 & 200 \\
\hline
\end{tabular}

Tabel 5. Keanekaragaman Serangga Pada Siang Hari

\begin{tabular}{rllcccc}
\hline NO & ORDO & \multicolumn{1}{c}{ GENUS } & JUMLAH & Pi & LnPi & -Pi(LnPi) \\
\hline 1 & Collembola & Isotomorus & 23 & 0,020 & $-3,092$ & 0,078 \\
2 & Collembola & Entomobrya & 31 & 0,027 & $-3,611$ & 0,097 \\
3 & Collembola & Hydroisotoma & 33 & 0,028 & $-3,575$ & 0,101 \\
4 & Collembola & Proisotoma & 41 & 0,035 & $-3,352$ & 0,117 \\
5 & Hymenoptera & Cardiocondyla & 42 & 0,036 & $-3,324$ & 0,119 \\
6 & Hymenoptera & Mirmica & 57 & 0,049 & $-3,015$ & 0,147 \\
7 & Hymenoptera & Iridomyrmex & 21 & 0,018 & $-4,017$ & 0,072 \\
8 & Hymenoptera & Dolichoderus & 136 & 0,119 & $-2,128$ & 0,253
\end{tabular}


Journal of Biology Learning

Volume 1, Issue 1, Page 36 - 46, March 2019

\begin{tabular}{rllcccc}
\hline NO & ORDO & GENUS & JUMLAH & Pi & LnPi & -Pi(LnPi) \\
\hline 9 & Coleoptera & Mycetophagus & 70 & 0,061 & $-2,796$ & 0,170 \\
10 & Coleoptera & Platydracus & 66 & 0,057 & $-2,864$ & 0,163 \\
11 & Coleoptera & Dendrocnotus & 32 & 0,028 & $-3,575$ & 0,100 \\
12 & Coleoptera & Batrisodes & 124 & 0,108 & $-2,225$ & 1,240 \\
13 & Coleoptera & Harpalus & 114 & 0,099 & $-2,312$ & 0,228 \\
14 & Coleoptera & Dyscinetus & 39 & 0,034 & $-2,381$ & 0,114 \\
15 & Coleoptera & Phaedonia & 30 & 0,026 & $-3,649$ & 0,094 \\
16 & Coleoptera & Paederus & 52 & 0,045 & $-3,101$ & 0,139 \\
17 & Blattaria & Periplaneta & 68 & 0,059 & $-2,830$ & 0,166 \\
18 & Blattaria & Platyzosteria & 78 & 0,068 & $-2,688$ & 0,182 \\
19 & Orthoptera & Gryllus & 56 & 0,049 & $-3,015$ & 0,147 \\
20 & Dermaptera & Euborellia & 29 & 0,025 & $-3,688$ & 0,092 \\
\hline & & & & & $\mathrm{H}^{\prime}=2,819$
\end{tabular}

Tabel 6. Pengukuran Faktor Abiotik

\begin{tabular}{ccccccc}
\hline \multirow{2}{*}{$\begin{array}{c}\text { STASIUN } \\
\text { KE- }\end{array}$} & $\begin{array}{c}\text { SUHU } \\
\text { TANAH } \\
{ }^{\circ} \mathbf{C}\end{array}$ & $\begin{array}{c}\text { KELEMBABAN } \\
\text { TANAH } \\
(\boldsymbol{\%})\end{array}$ & $\begin{array}{c}\text { pH } \\
\text { TANAH }\end{array}$ & $\begin{array}{c}\text { SUHU } \\
\text { UDARA } \\
{ }^{\circ} \mathbf{C}\end{array}$ & $\begin{array}{c}\text { KELEMBABAN } \\
\text { UDARA }\left({ }^{\circ} \mathbf{C}\right)\end{array}$ & $\begin{array}{c}\text { KADAR C- } \\
\text { ORGANIK } \\
\text { TANAH }\end{array}$ \\
\hline 1 & 28 & 50 & 6 & 29 & 92 & 1,08 \\
2 & 29 & 40 & 7 & 29 & 94 & 1,29 \\
3 & 28 & 40 & 6 & 30 & 93 & 1,96 \\
4 & 30 & 60 & 6 & 29 & 95 & 2,20 \\
5 & 29 & 50 & 7 & 30 & 93 & 1,66 \\
\hline RATA- & 28,8 & 48 & 6,4 & 29,4 & 93,4 & 8,19 \\
RATA & & & & & & \\
\hline
\end{tabular}

Analisis Keanekaragaman Dan Kemelimpahan Serangga Sore Hari

Tabel 7. Pengamatan Kemelimpahan Serangga pada Sore Hari

\begin{tabular}{|c|c|c|c|c|c|c|c|c|c|c|c|c|c|}
\hline \multirow[b]{2}{*}{ NO } & \multirow[b]{2}{*}{ ORDO } & \multirow[b]{2}{*}{ GENUS } & \multicolumn{5}{|c|}{ STASIUN } & \multirow[t]{2}{*}{ JMLH } & \multirow[t]{2}{*}{$\mathbf{K}$} & \multirow{2}{*}{$\begin{array}{l}\text { KR } \\
(\%)\end{array}$} & \multirow[t]{2}{*}{$\mathbf{F}$} & \multirow{2}{*}{$\begin{array}{l}\text { FR } \\
(\%)\end{array}$} & \multirow[t]{2}{*}{ NP } \\
\hline & & & 1 & 2 & 3 & 4 & 5 & & & & & & \\
\hline 1 & Collembola & Isotomorus & 3 & 4 & 9 & 4 & 0 & 20 & 4 & 3,44 & 0,8 & 5,33 & 8,77 \\
\hline 2 & Collembola & Entomobrya & 9 & 2 & 7 & 8 & 8 & 34 & 6,8 & 3,34 & 1 & 6,67 & 10,01 \\
\hline 3 & Collembola & Hydroisotoma & 4 & 1 & 15 & 5 & 15 & 40 & 8 & 3,93 & 1 & 6,67 & 10,6 \\
\hline 4 & Collembola & Proisotoma & 4 & 13 & 10 & 11 & 9 & 37 & 7,4 & 3,64 & 1 & 6,67 & 10,31 \\
\hline 5 & Hymenoptera & Cardiocondyla & 9 & 11 & 10 & 12 & 8 & 50 & 10 & 4,92 & 1 & 6,67 & 11,59 \\
\hline 6 & Hymenoptera & Mirmica & 11 & 10 & 12 & 12 & 16 & 61 & 12,2 & 6,01 & 1 & 6,67 & 12,68 \\
\hline 7 & Hymenoptera & Iridomyrmex & 3 & 3 & 4 & 7 & 5 & 22 & 4,4 & 2,16 & 0,8 & 5,33 & 7,49 \\
\hline 8 & Hymenoptera & Dolichoderus & 16 & 4 & 20 & 15 & 11 & 76 & 15,2 & 7,8 & 0,8 & 5,33 & 12,81 \\
\hline 9 & Coleoptera & Mycetophagus & 17 & 15 & 32 & 12 & 31 & 107 & 21,4 & 10,53 & 1 & 6,67 & 17,2 \\
\hline 10 & Coleoptera & Platydracus & 9 & 13 & 14 & 17 & 19 & 72 & 14,4 & 7,08 & 0,8 & 5,33 & 12,41 \\
\hline $\begin{array}{l}11 \\
12\end{array}$ & $\begin{array}{l}\text { Coleoptera } \\
\text { Coleoptera }\end{array}$ & $\begin{array}{c}\text { Dendrocnotus } \\
\text { Batrisodes }\end{array}$ & $\begin{array}{l}16 \\
21\end{array}$ & $\begin{array}{l}13 \\
23\end{array}$ & $\begin{array}{l}23 \\
15\end{array}$ & $\begin{array}{l}22 \\
31\end{array}$ & $\begin{array}{l}17 \\
12\end{array}$ & $\begin{array}{c}91 \\
102\end{array}$ & $\begin{array}{l}18,2 \\
20,4\end{array}$ & $\begin{array}{c}8,95 \\
10,03\end{array}$ & $\begin{array}{l}1 \\
1\end{array}$ & $\begin{array}{l}6,67 \\
6,67\end{array}$ & $\begin{array}{c}15,62 \\
16,7\end{array}$ \\
\hline 13 & Coleoptera & Harpalus & 16 & 21 & 20 & 12 & 28 & 87 & 17,4 & 8,56 & 1 & 6,67 & 15,23 \\
\hline 14 & Coleoptera & Dyscinetus & 23 & 11 & 18 & 17 & 12 & 71 & 14,2 & 6,98 & 1 & 6,67 & 13,65 \\
\hline 15 & Coleoptera & Phaedonia & 6 & 24 & 9 & 31 & 8 & 80 & 16 & 7,87 & 1 & 6,67 & 14,54 \\
\hline 16 & Coleoptera & Paederus & 12 & 18 & 9 & 15 & 6 & 66 & 13,2 & 6,49 & 0,8 & 5,33 & 11,82 \\
\hline
\end{tabular}



$179 \quad 196 \quad 227$ $231 \quad 205 \quad 1016$ $203,2 \quad 100$ 15 $100 \quad 200$

Tabel 8. Keanekaragaman Serangga Tanah Pada Sore Hari.

\begin{tabular}{lllllll}
\hline NO & \multicolumn{1}{c}{ ORDO } & \multicolumn{1}{c}{ GENUS } & JUMLAH & Pi & LnPi & -Pi(LnPi) \\
\hline 1 & Collembola & Isotomorus & 20 & 0,019 & $-3,963$ & 0,075 \\
2 & Collembola & Entomobrya & 34 & 0,033 & $-3,411$ & 0,122 \\
3 & Collembola & Hydroisotoma & 40 & 0,039 & $-3,244$ & 0,126 \\
4 & Collembola & Proisotoma & 37 & 0,036 & $-3,324$ & 0,119 \\
5 & Hymenoptera & Cardiocondyla & 50 & 0,049 & $-3,015$ & 0,147 \\
6 & Hymenoptera & Mirmica & 61 & 0,060 & $-2,813$ & 0,168 \\
7 & Hymenoptera & Iridomyrmex & 22 & 0,021 & $-3,863$ & 0,081 \\
8 & Hymenoptera & Dolichoderus & 76 & 0,074 & $-3,603$ & 0,192 \\
9 & Coleoptera & Mycetophagus & 107 & 0,105 & $-3,253$ & 0,157 \\
10 & Coleoptera & Platydracus & 72 & 0,070 & $-3,659$ & 0,186 \\
11 & Coleoptera & Dendrocnotus & 91 & 0,089 & $-2,419$ & 0,215 \\
12 & Coleoptera & Batrisodes & 102 & 0,100 & $-2,302$ & 0,230 \\
13 & Coleoptera & Harpalus & 87 & 0,085 & $-2,465$ & 0,209 \\
14 & Coleoptera & Dyscinetus & 71 & 0,069 & $-2,673$ & 0,184 \\
15 & Coleoptera & Phaedonia & 80 & 0,078 & $-2,511$ & 0,198 \\
16 & Coleoptera & Paederus & 66 & 0,064 & $-2,748$ & 0,175 \\
\hline & & & & & H'=2,574 \\
\hline
\end{tabular}

Tabel 9. Pengukuran Faktor Abiotik

\begin{tabular}{ccccccc}
\hline \multirow{2}{*}{$\begin{array}{c}\text { STASIUN } \\
\text { KE- }\end{array}$} & $\begin{array}{c}\text { SUHU } \\
\text { TANAH } \\
\left({ }^{\circ} \mathbf{C}\right)\end{array}$ & $\begin{array}{c}\text { KELEMBABAN } \\
\text { TANAH } \\
(\boldsymbol{\%})\end{array}$ & $\begin{array}{c}\text { pH } \\
\text { TANAH }\end{array}$ & $\begin{array}{c}\text { SUHU } \\
\text { UDARA } \\
\left({ }^{\circ} \mathbf{C}\right)\end{array}$ & $\begin{array}{c}\text { KELEMBABAN } \\
\text { UDARA }\left({ }^{\circ} \mathbf{C}\right)\end{array}$ & $\begin{array}{c}\text { KADARC- } \\
\text { ORGANIK } \\
\text { TANAH }\end{array}$ \\
\hline 1 & 26 & 45 & 6 & 28 & 93 & 1,08 \\
2 & 28 & 50 & 6 & 28 & 93 & 1,29 \\
3 & 26 & 45 & 6 & 29 & 94 & 1,96 \\
4 & 28 & 55 & 7 & 28 & 94 & 2,20 \\
5 & 29 & 60 & 7 & 29 & 94 & 1,66 \\
\hline RATA- & 27,4 & 51 & 6,4 & 28,4 & 93,6 & 8,19 \\
RATA & & & & & &
\end{tabular}

Keanekaragaman dan kemelimpahan serangga pada pagi hari

Berdasarkan tabel pengamatan diatas dapat diketahui bahwa pengamatan serangga pada pagi hari terdapat 4 ordo yang terdiri dari 18 genus. Serangga yang didapatkan yaitu ordo Collembola terdiri dari 5 genus yaitu Isotomorus, Entomobrya, Hydroisotoma, Proisotoma, dan Vertagopus ordo Hymenoptera terdiri dari 3 genus yaitu Mirmica, Iridomyrmex, danCardiocondyla , ordo Coleoptera terdiri dari 8 genus : Mycetophagus, Platydracus, Dendrocnotus, Batrisodes, Harpalus, Dyscinetus , Phaedonia , dan
Paederus. Sedangkan ordo Blattaria hanya terdiri dari 2 genus yaitu Periplaneta dan Platyzosteria.

Dari hasil penelitian pada pagi hari jumlah individu yang didapatkan di masing-masing stasiun berbeda-beda jumlahnya. Stasiun I diperoleh 105, stasiun II 123, stasiun III 192, stasiun IV 313 dan stasiun V 148 . Total serangga yang di peroleh dalam pengamatan adalah 1037. Jumlah yang didapatkan bervariasi hal ini di sebabkan oleh beberapa faktor seperti kondisi lingkungan, suhu tanah, kelembaban tanah, Ph tanah, kadar Corganik tanah, suhu udara dan juga 
kelembaban udara. Setelah diukur faktor abiotiknya hutan Bromo di pagi hari ratarata memiliki suhu tanah $26{ }^{\circ} \mathrm{C}$, Kelemaban tanah 53\%, pH 6,6, suhu udara $27,4{ }^{\circ} \mathrm{C}$ dan kelemaban udara sebesar 94,4 $\%$. Jumlah serangga paling banyak ditemukan pada stasiun ke-IV, dimana pada stasiun ini kadar C-organiknya paling tinggi yaitu 2, $20 \%$ seperti pada teori yang ada bahwa, Material organik tanah juga sangat menentukan kepadatan populasi mikroorganisme tanah. Serangga golongan saprofag hidupnya tergantung pada sisa daun yang jatuh. Komposisi dan jenis serasah daun dan banyaknya serasah itu menentukan kepadatan serangga. (Suin, 1997).

Dilihat dari kondisi lingkunganya stasiun IV lebih banyak ditumbuhi oleh berbagai jenis pohon yang bermacammacam sehingga seresah juga lebih banyak dari stasiun lain, organisme atau serangga banyak terdapat di lapisan tanah atas atau lapisan top soil (Sutedjo et al, 1996). Karena pada lapisan top soil ini pada permukaannya terdapat lapisan serasah daun yang terdiri dari daun baru jatuh dan telah mengurai sebagian dan bagian lain tumbuhan, yang mana lapisan serasah tersebut merupakan sumber makanan bagi serangga. (Sutedjo et al, 1996). Keberadaan dan kepadatan populasi suatu jenis serangga di suatu daerah sangat tergantung dari faktor lingkungan, yaitu lingkungan biotik dan abiotik. (Kimball, 1999).

Untuk mengetahui tingkat kemelimpahan serangga dapat diketahui dari INP pada masing-masing genus.Setelah hasil data pengamatan serangga pada pagi hari dianalisis terlihat bahwa INP tertinggi yaitu ordo Collembola pada genus Entomobrya dengan INP 19,14. Sedangkan INP terendah yaitu ordo Coleoptera genus Mycetophagus dengan INP 6, 76. Dari nilai INP dapat diketahui bahwa serangga paling dominan pada pagi hari yaitu yaitu ordo Collembola. Faktor abiotik yang sangat mendukung yaitu tingkat keasaman yang mana pada tingkat keasaman atau $\mathrm{pH}$ tanah pada penelitian di pagi hari yaitu berkisar 6-7. Menurut Suin (1997) ada serangga yang dapat hidup pada pada tanah yang $\mathrm{pH}$ - nya asam dan basa, yaitu Collembola. Ordo Collembola merupakan golongan serangga tanah yang hidup Proses dekomposisi bahan - bahan organik menurut Rahmawaty (2006) berlangsung sebagai berikut: pertama - tama perombak yang besar atau makrofauna (rayap, semut, dll) meremah - remah substansi yang telah mati, kemudian materi ini akan melalui usus dan akhirnya menghasilkan butiran butiran feses. Butiran - butiran feses tersebut akan dimakan oleh mesofauna (Collembola) yang hasil akhirnya akan dikeluarkan dalam bentuk feses pula.

Setelah diketahui INP masing-masing individu, maka dapat dihitung tingkat keanekaragaman serangga di Hutan Bromo diwaktu pagi hari. Dari beragai faktor biotik dan abiotik yang sudah diukur dalam penelitian, selanjutnya dianalisis dengan $H^{\prime}$ yaitu Indeks Shannon and Wiener. Dari data tersebut diperoleh $H$ 'sebesar $\mathbf{H}^{\prime}=\mathbf{2 , 7 1 4}$, ini berarti tingkat keanekaragaman serangga pada pagi hari tergolong kategori sedang karena berada pada kisaran 1,5-3,5

Keanekaragaman sedang. (Rahmawaty, 2006).

\section{Keanekaragaman dan kemelimpahan} serangga pada siang hari.

Hutan Bromo pada siang hari memiliki suhu tanah $28,8{ }^{\circ} \mathrm{C}$, Kelemaban tanah $48 \%, \mathrm{pH} 6,4$, suhu udara $29,4{ }^{\circ} \mathrm{C}$ dan kelemaban udara sebesar 93,4 \%. Jumlah serangga tanah yang didapatkan sebanyak 1134 individu yang terdiri dari 6 ordo 20 genus. Dengan rincian sebagai berikut: ordo Collembola terdiri dari 4 genus yaitu Isotomorus, Entomobrya, Hydroisotoma, dan Proisotoma, ordo Diptera terdiri 1 genus yaitu Drosopphila, ordo Hymenoptera terdiri dari 4 genus yaitu Mirmica, Iridomyrmex, Dolichoderus dan Cardiocondyla, ordo Coleoptera terdiri dari 8 genus : Mycetophagus, Platydracus, Dendrocnotus, Batrisodes, Harpalus, Dyscinetus , Phaedonia , dan Paederus, 
ordo Blattaria hanya terdiri dari 2 genus yaitu Periplaneta dan Platyzosteria, ordo Orthoptera terdiri dari 1 genus yaitu Gryllus dan ordo Dermaptera terdiri 1 genus yaitu Euborellia.

Dilihat dari jumlahnya serangga yang ditemukan paling banyak yaitu pada stasiun ke-IV sama dengan hasil penelitian di waktu pagi hari.Akan tetapi jenis serangga yang paling mendominasi pada pengamatan di siang hari yaitu ordo Hymenoptera atau serangga sebangsa semut, yang paling dominan yaitu genus Dolichoderus.

Serangga digolongkan menjadi beberapa golongan menurut (Suin 1997) yaitu serangga karnivora dimana makanannya adalah jenis serangga lainnya termasuk saprofag, sedangkan serangga yang tergolong kaprovora memakan sisa atau kotoran saprofag dan karnivora. Organisme yang tergolong mikroflora seperti jamur dan bakteri juga tergantung pada serasah dan serangga. Serangga ini termasuk serangga yang bersifat parasit, ada yang bersifat karnivor dan ada yang bersifat herivora. Serangga Dolichoderus termasuk pada golongan karnivora karena makananya jenis serangga tanah lainnya termasuk saprofa. Serangga ini paling banyak ditemui dipepohonan yang kering sehingga sering dijumpai pada siang hari dan kondisi lingkungan yang panas dengan suhu $\pm 28-29{ }^{\circ}$ C. (Anonim. 2011)

Kemelimpahan atau INP serangga di Hutan Bromo pada siang hari paling tinggi yaitu pada ordo genus Dolichoderus yaitu sebesar 17, 3. Dan INP terendah yaitu pada ordo Dermaptera genus Euobrellia yaitu 6, 1. Kemelimpahan serangga genus Dolichoderus sesuai dengan kondisi lingkungan terutama suhu tanah, dimana suhu tanah rata-rata $27,4^{\circ} \mathrm{C}$ dan suhu udara $28,4{ }^{\circ} \mathrm{C}$. Kondisi Hutan dengan suhu tersebut menjadikan serangga yang berhabitat ditempat yang kering seperti seresah. Nilai INP yang tertinggi selanjutnya yaitu ordo Coleptera dengan nilai INP sebesar 16,24.

Tingkat keanekaragaman serangga pada siang hari yaitu sebesar $\mathbf{2 , 8 1 9}$. Hal ini 44 menunjukan hasil yang lebih tinggi dibandingkan dengan pagi hari, terlihat dari jumlah genus yang terlihat pada tabel pengamatan bahwa pada siang hari serangga yang berhasil diamati sebanyak 20 genus sedangkan pada pagi hari hanya 8 genus saja.

\section{Keanekaragaman dan kemelimpahan serangga pada sore hari.}

Pada sore hari serangga yang didapatkan paling sedikit dibandingakan pada waktu pagi hari dan siang hari. Hanya terdapat 3 ordo yang terdiri 16 genus yaitu ordo Collembola terdiri dari 4 genus yaitu Isotomorus, Entomobrya, Hydroisotoma, dan Proisotoma, ordo Hymenoptera terdiri dari 4 genus yaitu Mirmica, Iridomyrmex, Dolichoderus dan Cardiocondyla, ordo Coleoptera terdiri dari 8 genus : Mycetophagus, Platydracus, Dendrocnotus, Batrisodes, Harpalus, Dyscinetus , Phaedonia, dan Paederus.

Kondisi lingkungan pada sore hari menunjukkan suhu tanah 27,4 ${ }^{\circ} \mathrm{C}$, Kelemaban tanah 51\%, pH 6,4, suhu udara $28,4{ }^{\circ} \mathrm{C}$ dan kelemaban udara sebesar 93,6 \%.Jika dilihat dari faktorfaktor tersebut hampir sama dengan kondisi lingkungan pada pagi hari, akan tetapi dari hasil yang diperoleh jumlah serangga yang didapat pada tabel bengamatan bereda dengan pengamatan pada pagi hari. Pengamatan serangga di waktu sore hari jumlahnya lebih sedikit dibandingkan pengamatan siang maupun pagi hari.

Selanjutnya jumlah indeks kemelimpahan (INP) serangga dalam pengamatan ini paling tinggi ditempati oleh serangga ordo coleoptera genus Mycetophagus dengan nilai 17,2 dan INP terendah pada ordo Collembola yaitu genus Isotomorus yaitu 8,77.

Indeks keanekaragaman serangga pada sore hari juga mempunyai nilai paling rendah dari pada pagi dan siang hari, yaitu $\mathbf{H}^{\prime}=\mathbf{2 , 5 7 4}$. Meskipun demikian tingkat keanekaragaman masih dalam kategori sedang karena masih berada pada kisaran $1,5 \geq \mathrm{H}^{\prime} \geq 3,5$. Dari hasil analisis 
data berikut dapat ketahui bahwa selain fator biotik seperti pertumbuhan populasi, interaksi antar spesies, kompetisi dan pemangsaan sangat terlihat faktor abiotik keadaan lingkungan suhu, kelembaban dan $\mathrm{Ph}$ sangat berpengaruh terhadap keberadaan hewan tanah terutama pada serangga baik jumlah maupun jenis serangganya.

Dari pembahasan tersebut dapat lihat perbedaan indeks keanekaragaman serangga sebagai berikut:

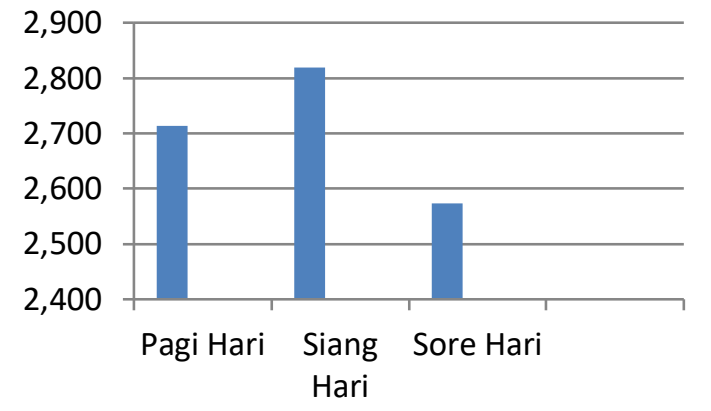

Gambar 4.1. Grafik Indeks Keanekaragaman Serangga.

Dari beberapa faktor abiotik yang tersebut suhu merupakan faktor Iingkungan yang menentukan/ mengatur aktivitas hidup serangga,yaitu bertindak sebagai faktor pembatas kemampuan hidup serangga. OIeh karena itu terdapat zona daerah suhu yang membatasi aktivitas kehidupan serangga. Zone-zone tersebut (untuk daerah tropis) yaitu: 1) Zone batas fatal atas, pada suhu tersebut serangga telah mengalami kematian, yaitu pada suhu $>48^{\circ} \mathrm{C}$; 2) Zone dorman atas, pada suhu ini aktivitas (organ tubuh eksterna) serangga tidak efektif, yaitu pada suhu $38^{\circ}-45^{\circ} \mathrm{C}$; 3) Zone efektifatas, pada suhu ini aktivitas serangga efektif pada suhu $30^{\circ}-38^{\circ} \mathrm{C}$; 4) Zone optimum, pada suhu $\pm 28^{\circ} \mathrm{C}$, aktivitas serangga adalah paling tinggi; 5) Zone efektif bawah, pada suhu ini aktivitas (organ interna dan eksterna) serangga efektif, yaitu pada suhu $27-15^{\circ} \mathrm{C}$; 6) Zone dorman bawah, pada suhu ini tidak ada aktivitas eksterna, yaitu pada suhu $15^{\circ} \mathrm{C}$; 7) Zone fatal bawah, pada suhu ini serangga telah mengalami kematian $\left( \pm 4^{\circ}\right.$.

Dari teori diatas dapat terlihat bahwa hasil pengamatan pada pagi, siang dan sore hari suhu di Hutan Bromo masih tergolong pada zona optimum, yaitu suhu berkisar $\pm 28^{\circ} \mathrm{C}$, akan tetapi kemelimpahan serangga paling tinggi terdapat pada siang hari yaitu berada pada suhu $\pm 29,4^{\circ} \mathrm{C}$ dimana suhu ini lebih tinggi dibandingkan suhu pagi dan sore hari. Sesuai dengan teori bahwa aktivitas serangga adalah paling tinggi Serangga akan lebih cepat menyelesaikan perkembangan hidupnya di daerah panas suhu berkisar $\pm 28^{\circ} \mathrm{C}$ daripada daerah dingin. (Jumar, 2000).

\section{Pembahasan hasil eksplorasi pelaksanaan penelitian sebagai sumber belajar}

Proses dan produk penelitian ini dapat dimanfaatkan di Sekolah Menengah Atas sebagai salah satu sumber belajar biologi tentang keanekaragaman arthopoda khususnya tentang insekta. Penerapan hasil penelitian ini dapat dilakukan dengan 2 alternatif, yang pertama yaitu dapat diterapkan diluar kelas dengan memanfaatkan lingkungan sekitar, dimana siswa diharapkan bisa mencoba mengamati serangga dilingkungan sekolah atau di Hutan sekitar sekolah bagi yang letak sekolahnya dekat dengan lokasi Hutan yang bisa digunakan sebagai pengamatan. Penerapan yang ke dua yaitu memanfaatkan produk penelitian yaitu sebagai bahan ajar pada saat pembelajaran di sekolah sesuai dengan materi atau $\mathrm{KD}$ yang sudah tertulis pada silabus.

Bidang studi biologi yang ditinjau dari tiga dimensi yaitu, obyek biologi, gejala atau peristiwa dan tingkat dari organisasi kehidupan, maka studi keanekaragaman dan kemelimpahan serangga tanah di Hutan Bromo Karanganyar sebagai salah satu sumber belajar biologi. Penelitian Anwari \& Subiyantoro (2017) menyatakan bahwa materi pembelajaran biologi yang dikemas dalam modul ajar biologi dapat memberdayakan kognitif peserta didik. 


\section{KESIMPULAN DAN SARAN Kesimpulan}

Berdasarkan data pengamatan dan pembahasan, maka dapat disimpulkan sebagai berikut: 1) Keanekaragaman serangga di Hutan Bromo Kabupaten Karanganyar termasuk dalam kategori sedang yaitu berada pada $1,5 \geq \mathrm{H}^{\prime} \geq 3,5 ; 2$ ) Keanekaragam serangga di Hutan Bromo Kabupaten Karanganyar paling tinggi yaitu pada siang hari dengan nilai $\mathrm{H}^{\prime}=2,819$ dan terendah pada sore hari denga nilai $\left.\mathrm{H}^{\prime}=2,574 ; 3\right)$ Indeks kemelimpahan serangga (INP) di Hutan Bromo Kabupaten Karanganyar tertinggi terjadi pada penelitian pagi hari yaitu ordo Collembola pada genus Entomobrya dengan nilai 19,14, sedangkan terendah pada siang hari yaitu ordo Dermaptera genus Euborellia yaitu 6, 1; 4) Terlihat bahwa faktor biotic sangat mempengaruhi dengan nilai keanekaragaman tertinggi pada siang hari ini menunjukkan bahwa pada siang hari proses kompetisi dan pemangsaan tidak banyak dilakukan oleh organisme atau tanah. Sedangkan faktor abiotik terlihat dari pengaruh kadar COrganik dan suhu, jumlah serangga paling banyak didapatkan pada stasiun IV dimana pada stasiun ini kadar C-organic paling tinggi yaitu 2,20\% dan serangga dapat hidup pada suhu $15^{\circ} \mathrm{C}-45^{\circ} \mathrm{C}$; 5). Proses dan produk penelitian ini dapat dimanfaatkan di Sekolah Menengah Atas seagai salah satu sumber belajar biologi tentang Keanekaragaman hewan kelas insekta .

\section{Saran}

Saran yang dituliskan dalam penelitian ini yaitu: 1) Kepada Guru, diharapkan guru bidang studi biologi dapat memanfaatkan benda dan kejadian lingkungan sekitar sebagai sumber belajar biologi; 2) Bagi siswa, diharapkan siswa dapat melakukan kegiatan penelitian sehingga dapat berfikir kreatif dan inovatif; 3) Masyarakat Umum, diharapkan agar tetap peduli dengan alam sekitar khususnya kelestarian hutan Bromo Kabupaten Karanganyar meningkatkan ekosistem alam agar tetap seimbang.

\section{DAFTAR PUSTAKA}

Borror, D. J., C. A. Triplehorn dan N. F.Johnson. (1997). Pengenalan PelajaranSerangga.Yogyakarta: Gadjah Mada University Press.

Jumar. (2000). Diakses dari http: //nurrohmanhadi. wordpress. com/ 2011/ 08/ 30/ biologi-serangga/

Nugroho, A. A., \& Subiyantoro, S. (2017). Pengembangan Modul Sistematika Tumbuhan Tinggi Berbasis Guided Discovery untuk Mengembangkan Kemampuan Berpikir Kritis Mahasiswa Pendidikan Biologi. BIOPEDAGOGI, 6(2), 19-24.

Rahmawaty. (2006). Studi Keanekaragaman Mesofauna Tanah di Kawasan Hutan Wisata Alam Sibolangit. Fakultas Pertanian Universitas Sumatera Utara www.library.usu.ac.id/modules.php. (Diakses 15 Desember 2015).

Soegianto, A. (1994). Ekologi Kuantitatif: Metode Analisis Populasi dan Komunitas. Surabaya: Usaha Nasional.

Suin, N. M. (1997). Ekologi Fauna Tanah. Jakarta: Bumi Aksara.

Winarno, R., Herawati, S., Istamar, S., Soebagio., I Komang A. Lingkungan Hidup Kita. Malang: PKPKLH Lembaga Penelitian IKIP Malang. 